\title{
Suppression of Induced Resistance in Cucumber Through Disruption of the Flavonoid Pathway
}

\author{
Bourlaye Fofana, Nicole Benhamou, David J. McNally, Caroline Labbé, \\ Armand Séguin, and Richard R. Bélanger
}

First, third, fourth, and sixth authors: Laboratoire de Biocontrôle, Département de Phytologie, Université Laval, Sainte Foy, Québec, Canada G1K 7P4; first and fifth authors: Natural Resources Canada, Canadian Forest Service, Laurentian Forestry Center, 1055 rue du P.E.P.S., P.O. Box 3800, Sainte Foy, Québec, Canada, G1V 4C7; and second author: Département de Phytologie, Recherche en Sciences de la Vie et de la Santé, Pavillon C.E. Marchand, Université Laval, Sainte Foy, Québec, Canada G1K 7P4. Accepted for publication 2 September 2004.

\begin{abstract}
Fofana, B., Benhamou, N., McNally, D. J., Labbé, C., Séguin, A., and Bélanger, R. R. 2005. Suppression of induced resistance in cucumber through disruption of the flavonoid pathway. Phytopathology 95:114-123.

In this study, cucumber plants (Cucumis sativus) expressing induced resistance against powdery mildew (caused by Podosphaera xanthii) were infiltrated with inhibitors of cinnamate 4-hydroxylase, 4-coumarate:CoA ligase (4CL), and chalcone synthase (CHS) to evaluate the role of flavonoid phytoalexin production in induced disease resistance. Light and transmission electron microscopy demonstrated ultrastructural changes in inhibited plants, and biochemical analyses determined levels of CHS and $\beta$-glucosidase enzyme activity and $4 \mathrm{CL}$ protein accumulation. Our results

showed that elicited plants displayed a high level of induced resistance. In contrast, down regulation of CHS, a key enzyme of the flavonoid pathway, resulted in nearly complete suppression of induced resistance, and microscopy confirmed the development of healthy fungal haustoria within these plants. Inhibition of 4CL ligase, an enzyme largely responsible for channeling phenylpropanoid metabolites into the lignin pathway, had little effect on induced disease resistance. Biochemical analyses revealed similar levels of 4CL protein accumulation for all treatments, suggesting no alterations of nontargeted functions within inhibited plants. Collectively, the results of this study support the idea that induced resistance in cucumber is largely correlated with rapid de novo biosynthesis of flavonoid phytoalexin compounds.
\end{abstract}

Cucumber (Cucumis sativus L., family Cucurbitaceae) and the powdery mildew fungus Podosphaera xanthii (syn. Sphaerotheca fuliginea auct. p.p.) are a convenient model for examining hostpathogen interactions. Accordingly, several elicitor-induced defense responses were reported for this pathosystem, including the lignification of cell walls $(2,20)$, increased activities for pathogenesis-related (PR) proteins such as chitinases, peroxidases, and $\beta$-1,3-glucanases $(11,22,29,36)$, and more recently, production of flavonoid phytoalexins $(9,10,14,26,27,41)$. Milsana, a commercial preparation made from the leaves of the giant knotweed plant (Reynoutria sachalinensis L.), is an eliciting mixture containing proteins, glycoproteins, peptides, carbohydrates, and lipids that signals the presence of the pathogen and triggers defense responses in a non-cultivar-specific manner $(9,10,22)$. In cucumber, Milsana induced resistance against $P$. xanthii and this resistance correlated with increased mRNA accumulation and greater extractable enzymatic activity for chalcone synthase (CHS) and chalcone isomerase, two key enzymes of the flavonoid pathway (17). Recently, it was found that rapidly synthesized $C$-glycosyl flavonoid phytoalexins, known as cucumerins, accumulated at the sites of fungal penetration within Milsana-elicited cucumber plants $(26,27)$. Despite recent advances in the understanding of induced resistance for this species, the importance of the role played by phytoalexins, compared with that of other defense responses reported for cucumber, is poorly understood.

The phenylpropanoid pathway in higher plants is responsible for generating metabolic intermediates directed into several path-

Corresponding author: R. R. Bélanger

E-mail address: richard.belanger@plg.ulaval.ca

DOI: 10.1094/PHYTO-95-0114

(c) 2005 The American Phytopathological Society ways, including the lignin and flavonoid pathways $(12,25,40)$. 4-Coumarate:CoA ligase (4CL) plays a particularly important role in plant defense reactions because of its position joining the phenylpropanoid pathway with lignin and flavonoid branch pathways (Fig. 1). In fact, different isoforms of 4CL direct carbon flow to the diverse pathways of phenylpropanoid metabolism according to different substrate preferences. For example, 4CL3 (a class II 4CL) has a high affinity for 4-coumarate, while 4CL1 and 4CL2 have strong affinities for 4-caffeate $(1,13,39)$. Thus, Ehlting et al. (13) and Stuible et al. (39) hypothesized that the primary function of class II $4 \mathrm{CL}$ is to channel 4-coumarate to the first enzyme of the flavonoid pathway, CHS.

Given the importance of the secondary metabolites produced by phenylpropanoid metabolism, potent chemical inhibitors have been developed for biosynthetic enzymes leading to lignin and flavonoid branch pathways. For instance, $\alpha$-aminooxy- $\beta$-phenylpropionic acid is an inhibitor of phenylalanine ammonia-lyase $(5,6,33)$. Piperonylic acid (PA) mimics cinnamic acid, the natural substrate of cinnamate 4-hydroxylase $(\mathrm{C} 4 \mathrm{H})$, and is a specific inhibitor of $\mathrm{C} 4 \mathrm{H}(37,38)$. 3,4-Methylenedioxy cinnamic acid (MDCA) is a structural analogue of 4-hydroxy cinnamic acid and is a reported inhibitor of 4CL $(19,30,37)$, and cycloheximide (CHX) is an efficient inhibitor of CHS transcription (7,23). Although the specificity of inhibitors has been debated $(4,38)$, previous reports using enzyme inhibitors such as PA have demonstrated that its impact on nontargeted plant function was minimal (37). Moreover, addition of CHX was shown to decrease the accumulation of CHS transcripts, without affecting the transcriptional level of constitutive genes in Arabidopsis thaliana and parsley (Petroselinum crispum) $(7,15,23)$.

The objective of this study was to evaluate the role of flavonoid phytoalexin production, lignification, and chitinases in disease resistance for cucumber. To this end, elicited cucumber plants ex- 
pressing induced resistance against powdery mildew were infiltrated with PA, MDCA, and $\mathrm{CHX}$, reported inhibitors of $\mathrm{C} 4 \mathrm{H}$, 4CL, and the translation of the CHS transcript, respectively (7, 19,37). Disease incidence was closely monitored over a period of 4 weeks. Light and transmission electron microscope investigations coupled with cytochemical labeling of chitin were used to document ultrastructural changes in inhibited plants. In order to determine the effects of inhibitor treatments on cucumber plants, biochemical methods were used to analyze protein levels of 4CL and enzyme activity of CHS and $\beta$-glucosidase.

\section{MATERIALS AND METHODS}

Chemicals. PA, MDCA, and CHX were purchased from Sigma Chemical (St. Louis, MO), dissolved in $\mathrm{H}_{2} \mathrm{O}$, and diluted to 0.5 to 1,3 , and $0.5 \mathrm{mM}$, respectively.

Plant material. Cucumber plants (C. sativus cv. Corona) were grown as described by Wurms et al. (41). Briefly, seeds were planted in Pro-mix (Premier Horticulture, Rivière du Loup, Québec, Canada) and watered daily until emergence. Seedlings were then placed in a climate-controlled growth chamber maintained at $23^{\circ} \mathrm{C}$, with a $16-\mathrm{h}$ photoperiod $\left(145 \mu \mathrm{E} \mathrm{m} \mathrm{m}^{-2} \mathrm{~s}^{-1}\right)$. Plants were then fertilized with a sterile nutrient solution $(\mathrm{N}: \mathrm{P}: \mathrm{K}$, 7:11:27) starting at the one- to two-leaf stage (3 to 4 weeks). Inoculation of cucumber plants with $P$. xanthii (syn. S. fuliginea) was performed at the four- to six-leaf stage (approximately 6-week-old plants) and was done by shaking the leaves of infected plants over uninfected plants. Uninoculated A. thaliana (ecotype Colombia), poplar (Populus tremuloides), and cucumber plants were grown and fertilized in a separate climatecontrolled growth chamber under the same conditions. Tissue harvested from healthy plants of these two species served as positive controls for $4 \mathrm{CL}$ protein expression and $\beta$-glucosidase enzyme activity.

Inhibitor and elicitor treatments and disease assessment. Inhibitors were injected into the leaves of cucumber plants with a medical intravenous infusion system $\left(0.5 \mathrm{ml} \mathrm{h}^{-1}\right.$ Multiday Infusor Syringe; Baxter, Deerfield, IL). As a preliminary test, injection of $5 \mathrm{ml}$ of an aqueous blue copper sulfate solution $\left(\mathrm{CuSO}_{4}, 1 \mathrm{mg} \mathrm{ml}^{-1}\right)$ established that the solution had translocated throughout the leaf tissue within $10 \mathrm{~h}$.

Upon appearance of the first signs of infection covering approximately $2 \%$ of leaf area (4 to 6 days after inoculation), plants were segregated using Miracloth tissue. Inoculated (I+) and uninoculated (I-) plants were sprayed until runoff with an aqueous solution of Milsana $(0.5 \%, \mathrm{vol} / \mathrm{vol})$ once a week for 4 weeks (the duration of the experiment) and were referred to as $\mathrm{I}+\mathrm{M}+$ and $\mathrm{I}-\mathrm{M}+$, respectively. Following the first Milsana treatment, I+M+ plants selected at random were syringe-injected through the petiole of the third leaf with $5 \mathrm{ml}$ of 0.5 or $1 \mathrm{mM}$ PA, $3 \mathrm{mM}$ MDCA, or $0.5 \mathrm{mM} \mathrm{CHX,} \mathrm{and} \mathrm{were} \mathrm{designated} \mathrm{I}+\mathrm{M}+(\mathrm{PA})$, $\mathrm{I}+\mathrm{M}+(\mathrm{MDCA})$, and $\mathrm{I}+\mathrm{M}+(\mathrm{CHX})$, respectively. As controls, selected inoculated Milsana-elicited plants were syringe-injected with $5 \mathrm{ml}$ of pure water and were referred to as $\mathrm{I}+\mathrm{M}+\left(\mathrm{H}_{2} \mathrm{O}\right)$. Disease assessment was carried out on a weekly basis following treatment with Milsana, or water, for 4 weeks according to the system developed by Nicot et al. (31). The experiment was repeated three times, and data were collected from individual injected leaves and entire plants.

Extraction of enzymes and proteins from bacterial and plant material. As source of enzymes and proteins, recombinant 4CL2 and 4CL3 constructs were propagated and expressed in Escherichia coli (strain M15) (Qiagen, Mississauga, Canada) according to standard practice $(13,24,28)$. Briefly, transformed

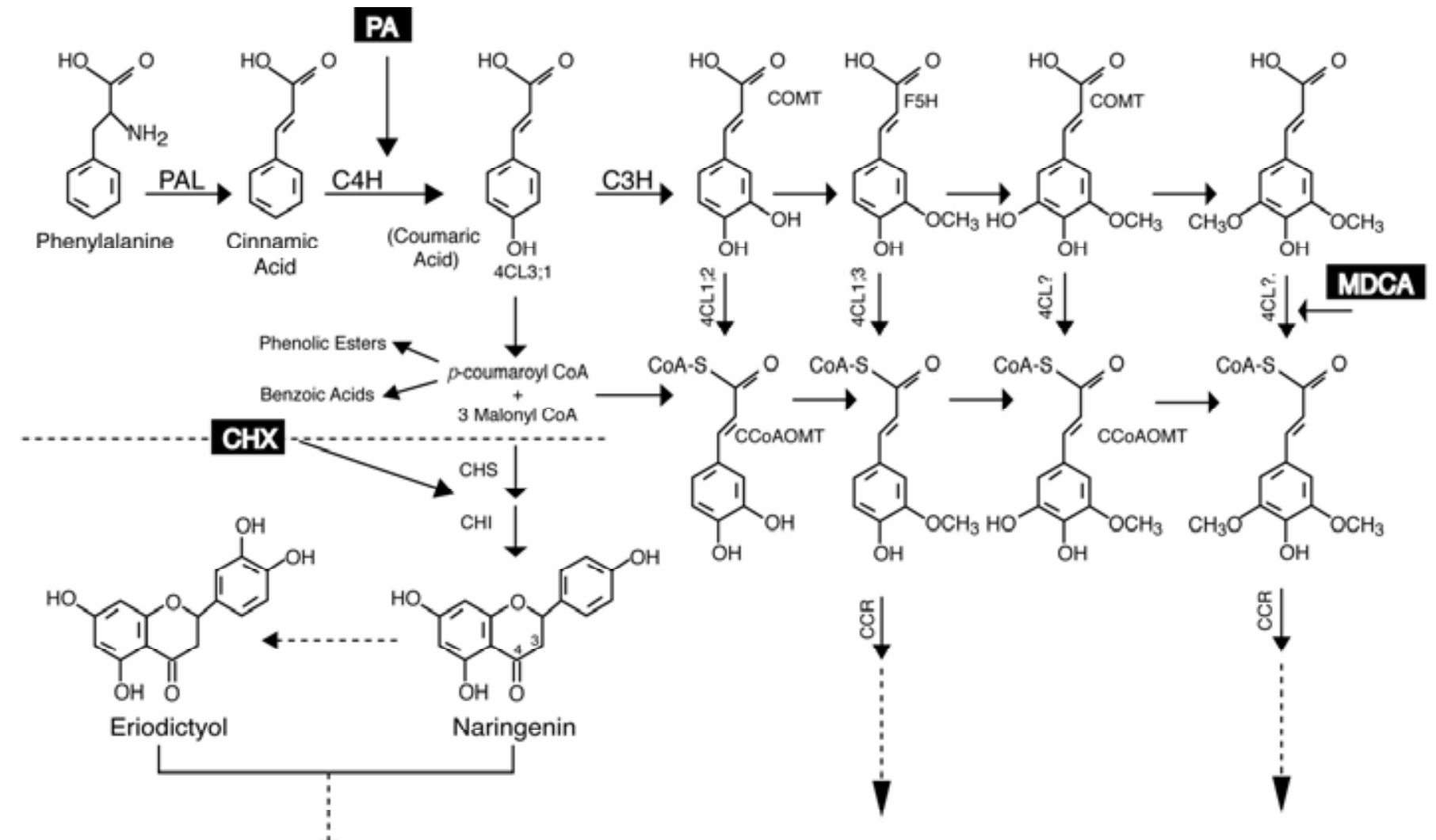

FLAVONOIDS

Lignin, wall-bound phenolics, etc.

Fig. 1. The phenylpropanoid pathway in plants leading to flavonoid and lignin biosynthesis showing the enzymes inhibited by piperonylic acid (PA), 3,4-methylenedioxy cinnamic acid (MDCA), and cycloheximide (CHX). PAL, phenylalanine ammonia-lyase; C4H, cinnamate 4-hydroxylase; C3H, cinnamate 3-hydroxylase; COMT, caffeate 3-O-methyltransferase; F5H, ferulate 5-hydroxylase; CHS, chalcone synthase; CHI, chalcone isomerase; 4CL, 4-coumarate:CoA ligase; CCoAOMT, caffeoyl-CoA 3-O-methyltransferase; and CCR, cinnamoyl-CoA reductase $(24,37)$. 
E. coli cultures were first induced with $2 \mathrm{mM}$ IPTG, an analogue of galactose, for $5 \mathrm{~h}$ followed by centrifugation $(14,000 \mathrm{rpm}$, $4^{\circ} \mathrm{C}$ ). The bacterial pellet was then sonicated in $200 \mathrm{mM}$ Tris- $\mathrm{HCl}$ (pH 7.8), and clear lysates were supplemented with $30 \%$ glycerol and stored at $-20^{\circ} \mathrm{C}$.

In a similar manner, 4CL enzymes were extracted from cucumber, A. thaliana, and poplar tissues. Harvested plant tissues $(200 \mathrm{mg}$ ) were first ground in liquid nitrogen, mixed in $1 \mathrm{ml}$ of buffer containing $200 \mathrm{mM}$ Tris- $\mathrm{HCl}(\mathrm{pH} \mathrm{7.8)}$ ) and $15 \mathrm{mM}$ 2-mercaptoethanol, and placed on a rotary shaker for $20 \mathrm{~min}$ in the presence of DOWEX 1× 2-200 resin (20 mg) (Aldrich Chemical, Sheboygan, WI) at $4^{\circ} \mathrm{C}$ to clear supernatant by fixing pigments. Following centrifugation $\left(14,000 \mathrm{rpm}, 4^{\circ} \mathrm{C}\right)$, the supernatant was supplemented with $30 \%$ glycerol and stored at $-20^{\circ} \mathrm{C}$.

Analysis of protein synthesis and CHS enzymatic activity. To determine the effects of CHX on the general plant protein synthesis, $4 \mathrm{CL}$ protein accumulation and $\beta$-glucosidase activity were analyzed within total protein extracts. For western blot analysis of recombinant and extracted 4CL, bacterial lysates containing recombinant 4CL were loaded on a Ni NTA Spin Column (Qiagen) and eluted with an imidazole buffer $(250 \mathrm{mM})$ according to the manufacturer's recommendation. Approximately $1 \mu \mathrm{g}$ of purified $4 \mathrm{CL}$ recombinant proteins and $20 \mu \mathrm{g}$ of total plant proteins from $\mathrm{I}+\mathrm{M}+$ and $\mathrm{I}+\mathrm{M}+(\mathrm{CHX})$ cucumber plants were electrophoresed in $12 \%$ sodium dodecyl sulfate-polyacrylamide gel electrophoresis denaturing gel. As controls, total protein extracts prepared from A. thaliana and poplar plants were electrophoresed $(20 \mu \mathrm{g})$ using the same conditions. Electrophoresed proteins were then blotted on a nitrocellulose membrane and probed by reaction with a polyclonal antiserum raised against parsley 4CL, according to Ragg et al. (35). For analysis of $\beta$-glucosidase activity, total protein extracts were first prepared from the tissues of I+M-, I+M+, I-M-, and $\mathrm{I}+\mathrm{M}+(\mathrm{CHX})$ cucumber plants, as well as from A. thaliana. The level of $\beta$-glucosidase activity was quantified within these extracts according to the protocol developed by Politycka (34), and expressed as millimole of para-nitrophenyl pyranoside per microgram of protein. The activity was measured from leaves harvested in three separate experiments.
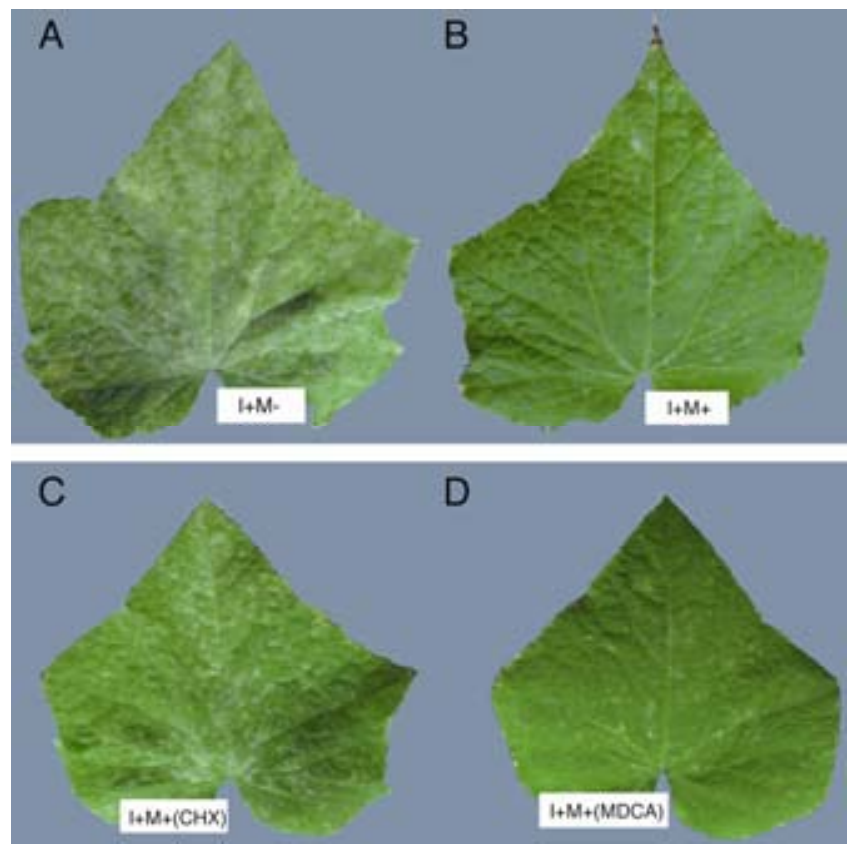

Fig. 2. A, A leaf harvested from an inoculated, nonelicited (I+M-) cucumber plant, and $\mathbf{B}$, a leaf harvested from an inoculated and elicited (I+M+) cucumber plant. C and D, Cucumber leaves harvested from inoculated and elicited cucumber plants infiltrated with cycloheximide $\mathrm{I}+\mathrm{M}+(\mathrm{CHX})$ and 3,4methylenedioxy cinnamic acid I+M+(MDCA), respectively. All leaves were harvested 2 weeks after infiltration with inhibitors.
CHS activity was determined within total protein extracts prepared from the tissues of $\mathrm{I}+\mathrm{M}-, \mathrm{I}+\mathrm{M}+(\mathrm{CHX})$, and $\mathrm{I}+\mathrm{M}+$ cucumber plants using the methodology developed by O'Neill et al. (32), with minor modifications. Briefly, in a total volume of $110 \mu \mathrm{l}, 13.5 \mu \mathrm{l}$ of coumaroyl-CoA $(205 \mu \mathrm{M}), 5 \mu \mathrm{l}$ of $\left({ }^{14} \mathrm{C}\right)$ malonyl-CoA $\left(2.2 \mathrm{Gbq} \mathrm{mmol}^{-1}, 60 \mathrm{mCi} \mathrm{mmol}^{-1}\right)$, and $20 \mu \mathrm{lof}$ crude CHS enzyme extract were incubated in $71.5 \mu \mathrm{l}$ of reaction buffer (700 mM K-Pi, pH 8.0; $2 \%$ bovine serum albumin) at $37^{\circ} \mathrm{C}$ for $1 \mathrm{~h}$. Following two extractions of the reaction product with $200 \mu \mathrm{l}$ of ethyl acetate $(2 \times 200 \mu \mathrm{l})$, the amount of radioactivity within a $250-\mu$ sample of the combined ethyl acetate extracted phase was estimated by scintillation counting. The identity of the flavonoid reaction product was confirmed using thin layer co-chromatography with toluene/chloroform/ethyl acetate (40:25:35) as the developing solvent system and a standard for naringenin purchased from Aldrich Chemical Company. The activity was measured from leaves harvested in three separate experiments.

Light and transmission electron microscopy. Seven days after infiltration with inhibitors, tissue samples were harvested from the third leaf of all plants. Leaf samples were dissected into $1-\mathrm{mm}^{2}$ sections, fixed overnight at $4{ }^{\circ} \mathrm{C}$ in $3 \%$ (vol/vol) glutaraldehyde per $0.1 \mathrm{M}$ sodium cacodylate buffer $(\mathrm{pH} 7.2)$, postfixed for $1 \mathrm{~h}$ at ambient temperature using $1 \%$ (wt/vol) osmium tetroxide, dehydrated by soaking in a series of aqueous ethanol solutions (30 to 100\%), and embedded in Jemdeb 812 Resin (Canemco Inc., St. Laurent, Quebec). For light microscopy observations, thick sections ( 1 to $2 \mu \mathrm{m}$ ) were cut with a glass knife and stained for $45 \mathrm{~s}$ with $0.2 \%(\mathrm{wt} / \mathrm{vol})$ toluidine blue $\mathrm{O}$ in $2 \%(\mathrm{wt} / \mathrm{vol})$ sodium borate.

For transmission electron microscopy, thin sections $(0.1 \mu \mathrm{m})$ were cut with a diamond knife and samples were examined with a transmission microscope (JEOL, Tokyo) operating at $80 \mathrm{kV}$. Cytochemical labeling of chitin within tissue samples was performed according to Benhamou et al. (3). Briefly, gold particles (12 $\mathrm{nm}$ in diameter) were first prepared according to the method reported by Frens (18). Wheat germ agglutinin (WGA), a lectin with $N$-acetylglucosamine binding specificity, was used as the second-step reagent. A highly specific cytochemical ovomucoidgold conjugate probe ( $\mathrm{pH}$ 6.0) was added to tissue samples as the third and final reagent.

\section{RESULTS}

Disease incidence following elicitor and inhibitor treatments. In this study, Milsana-treated plants inoculated with $P$. xanthii $(\mathrm{I}+\mathrm{M}+)$ had a low level of infection that never exceeded $5 \%$ of leaf surfaces for the duration of the experiment (4 weeks). In contrast, infection for nonelicited plants (I+M-) progressed rapidly and covered approximately $80 \%$ of leaf surfaces (Fig. 2A and B). These results were consistent with previous studies examining the prophylactic effects of Milsana in powdery mildewinfected cucumber plants $(9,10,17,41)$.

Infiltration with a blue-green $\mathrm{CuSO}_{4}$ solution demonstrated extensive translocation of fluids within cucumber leaf tissues at $24 \mathrm{~h}$ after injection; the margins and venation of infiltrated leaves were typically blue-green in color (data not shown). Despite receiving an eliciting treatment, the level of infection for CHX-infiltrated $\mathrm{I}+\mathrm{M}+(\mathrm{CHX})$ plants was significantly higher $(46 \%$ coverage of leaf surface) compared with that of I+M+ plants (Fig. 2C). Infiltration with MDCA in $\mathrm{I}+\mathrm{M}+(\mathrm{MDCA})$ yielded an intermediate level of infection $(27 \%)$ between that of $\mathrm{I}+\mathrm{M}+(\mathrm{CHX})$ plants and $\mathrm{I}+\mathrm{M}+$ plants (Fig. 2D). Disease assessment for $\mathrm{I}+\mathrm{M}+(\mathrm{PA})$ plants was difficult because infiltration with PA caused cytotoxic reactions at both 0.5 and $1 \mathrm{mM}$, as evidenced by the chlorotic appearance of leaf tissue. Injection with water alone in $\mathrm{I}+\mathrm{M}+\left(\mathrm{H}_{2} \mathrm{O}\right)$ plants caused no substantial differences compared with that of noninfiltrated $\mathrm{I}+\mathrm{M}+$ plants (data not shown). 
Analysis of protein synthesis and CHS enzymatic activity. Western blot analysis of purified recombinant bacterial lysates confirmed the affinity of the polyclonal antiserum raised against parsley 4CL for 4CL3 and 4CL2 (Fig. 3A). Similarly, total protein extracts prepared from the tissues of all plants investigated reacted with the 4CL antibodies (Fig. 3A). Of particular importance, no differences were observed for the presence of 4CL within $\mathrm{I}+\mathrm{M}+(\mathrm{CHX})$ plants compared with $\mathrm{I}+\mathrm{M}+$ cucumber plants, A. thaliana, or poplar, indicating that $\mathrm{CHX}$ had no effect on $4 \mathrm{CL}$ protein synthesis (Fig. 3A). When $\beta$-glucosidase activity was assayed, no significant differences were observed for $\mathrm{I}+\mathrm{M}+(\mathrm{CHX})$ plants compared with uninhibited I+M-, I+M+, I-M- cucumber plants, or A. thaliana (Fig. 3B), suggesting that CHX did not have a general damaging effect on synthesis of proteins such as $\beta$ glucosidase. In contrast, analysis of CHS revealed greater enzymatic activity for $\mathrm{I}+\mathrm{M}+$ plants compared with that of $\mathrm{I}+\mathrm{M}-$ or $\mathrm{I}+\mathrm{M}+(\mathrm{CHX})$ cucumber plants (Fig. 3C). In particular, the level of CHS activity for $\mathrm{I}+\mathrm{M}+(\mathrm{CHX})$ plants was 1.6 times lower than that of susceptible I+M- plants and 4.4 times lower than that of disease-resistant I+M+ cucumber plants (Fig. 3C).

Light microscope observations. Light microscope observations paralleled the disease incidence observed at the whole plant level (Fig. 4). On inoculated nonelicited I+M- cucumber plants, fungal cells formed germ tubes at the cell surface and penetrated the epidermis to form well-developed multilobed haustoria (Fig. 4A). In inoculated Milsana-elicited ( $+\mathrm{M}+$ ) plants, papilla formation was observed (Fig. 4B) and haustoria were often encased in an amorphous material that formed at the point of fungal penetration (Fig. 4C to E). Papilla development at the site of appressorium formation was also observed as a primary plant defense response (Fig. 4E).

Treatment with PA resulted in pronounced plant tissue alterations as judged by the extent of collapsed and disorganized leaf cells (Fig. 4F), corroborating the phytotoxic reactions observed for the leaves of PA-infiltrated plants. For elicited MDCA-infiltrated $\mathrm{I}+\mathrm{M}+(\mathrm{MDCA})$ cucumber leaf tissue, fungal haustoria were sometimes collapsed and degraded (Fig. 4G and H). Although aggregated haustoria were often encased in a material that stained densely with toluidine blue, the presence of amorphous material was not as extensive and regular as that observed in $\mathrm{I}+\mathrm{M}+$ plants (Fig. 4B). In contrast, multilobed haustoria were abundant in epidermal cells of $\mathrm{CHX}$-infiltrated $\mathrm{I}+\mathrm{M}+(\mathrm{CHX})$ plants, and mycelial structures at the plant leaf surface appeared healthy and turgid (Fig. 4I and J).

Transmission electron microscope observations. Electron microscope observations of $\mathrm{I}+\mathrm{M}-$ plants revealed that infection with $P$. xanthii resulted in the formation of multilobed haustoria characterized by ovoid central bodies surrounded by an extrahaustorial membrane (Fig. 5A). Following cytochemical labeling, it was shown that the haustorial wall was labeled by the WGA/ ovomucoid-gold complex, whereas the extrahaustorial matrix and extrahaustorial membrane were free of labeling (Fig. 5B).

Within the epidermal cells of inoculated elicited I+M+ cucumber plants, haustoria were visibly degraded and collapsed (Fig. 6A to C). In most cases, haustorial lobes were retracted and compressed against the haustorial body, and organelles within haustoria of I+M+ plants were no longer discernible (Fig. 6A to C). Fungal hyphae at the plant cell surface frequently contained aggregated cytoplasm (Fig. 6A), and collapsed haustoria were surrounded by an amorphous material that did not react with the WGA/ ovomucoid-gold complex that labels chitin (Fig. 6B and C). In contrast, the walls of fungal haustoria were frequently heavily labeled (Fig. 6C).

For I+M+(MDCA) epidermal cells, irregular defense reaction was associated with elongated vesicular and collapsed haustoria encased in a granular matrix resembling callose (Fig. 7A). For $\mathrm{I}+\mathrm{M}+(\mathrm{CHX})$ plants, the morphology and ultrastructure of haustoria were very similar to those observed for I+M- plants (Fig. 7B to D). Of particular importance, healthy multilobed haustoria were consistently observed within the epidermis of $\mathrm{I}+\mathrm{M}+(\mathrm{CHX})$ cucumber plants.

\section{DISCUSSION}

During the last 4 decades, the cucumber-powdery mildew pathosystem has been investigated relative to mechanisms under-
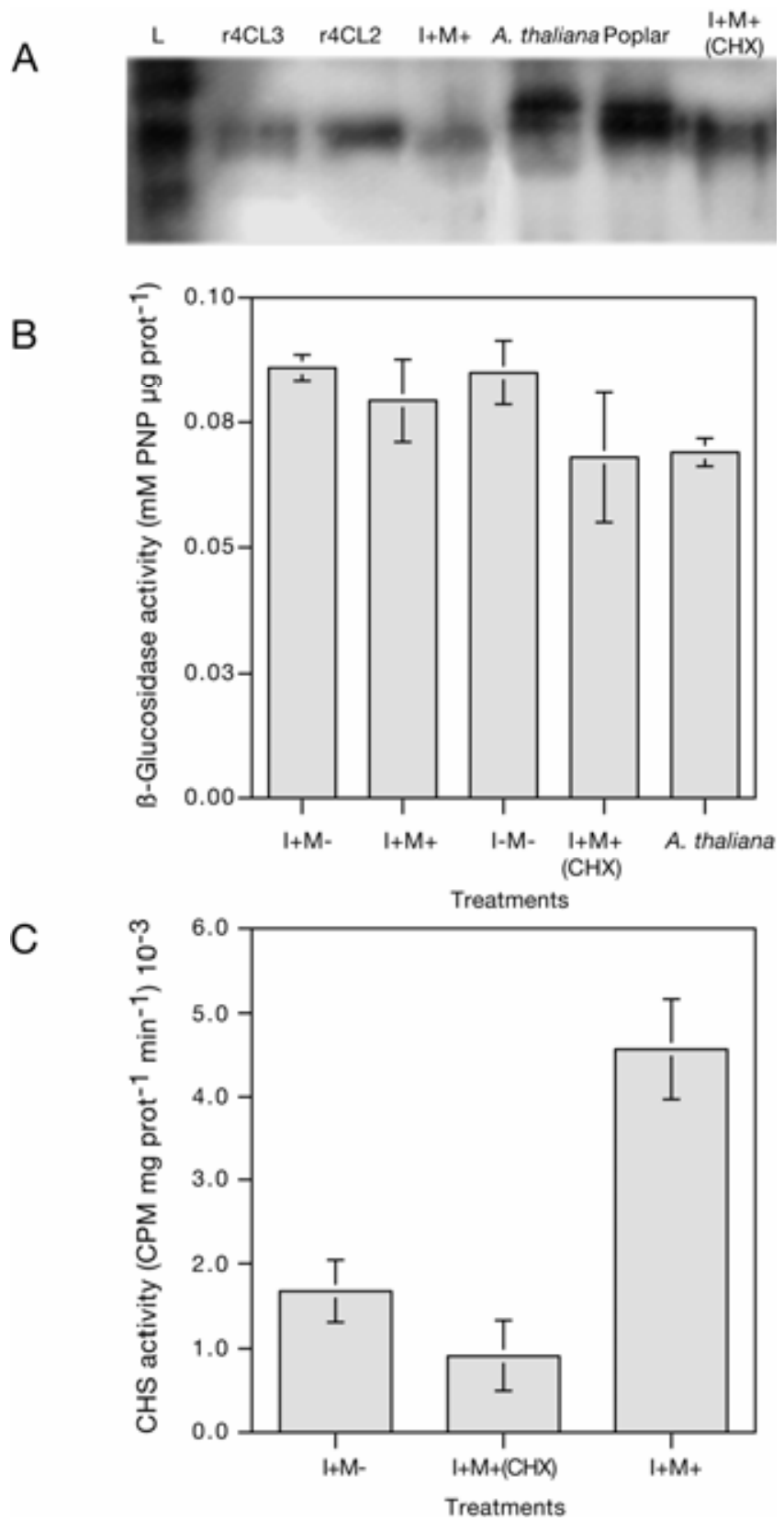

Fig. 3. A, Western blot analysis of recombinant (r), and extracted 4coumarate:CoA ligase (4CL) enzymes prepared from elicited cucumber plants inoculated with Podosphaera xanthii $(\mathrm{I}+\mathrm{M}+)$, Arabidopsis thaliana, poplar, and inoculated elicited cucumber plants infiltrated with cycloheximide $\mathrm{I}+\mathrm{M}+(\mathrm{CHX})$. Immunodetection was performed using a polyclonal antiserum raised against parsley $4 \mathrm{CL}$. Protein loading was equal in all treatments. B, $\beta$-Glucosidase enzyme activity in nonelicited cucumber plants inoculated with P. xanthii $(\mathrm{I}+\mathrm{M}-)$, elicited inoculated cucumber $(\mathrm{I}+\mathrm{M}+)$ plants, nonelicited uninoculated (I-M-) cucumber plants, elicited inoculated cucumber plants infiltrated with cycloheximide $\mathrm{I}+\mathrm{M}+(\mathrm{CHX})$, and A. thaliana plants. C, Chalcone synthase (CHS) enzyme activity in nonelicited cucumber plants inoculated with $P$. xanthii $(\mathrm{I}+\mathrm{M}-)$, elicited inoculated cucumber plants infiltrated with cycloheximide $\mathrm{I}+\mathrm{M}+(\mathrm{CHX})$, and elicited inoculated (I+M+) cucumber plants. Vertical bars in $\mathbf{B}$ and $\mathbf{C}$ represent the standard error from the means of three separate measurements. 

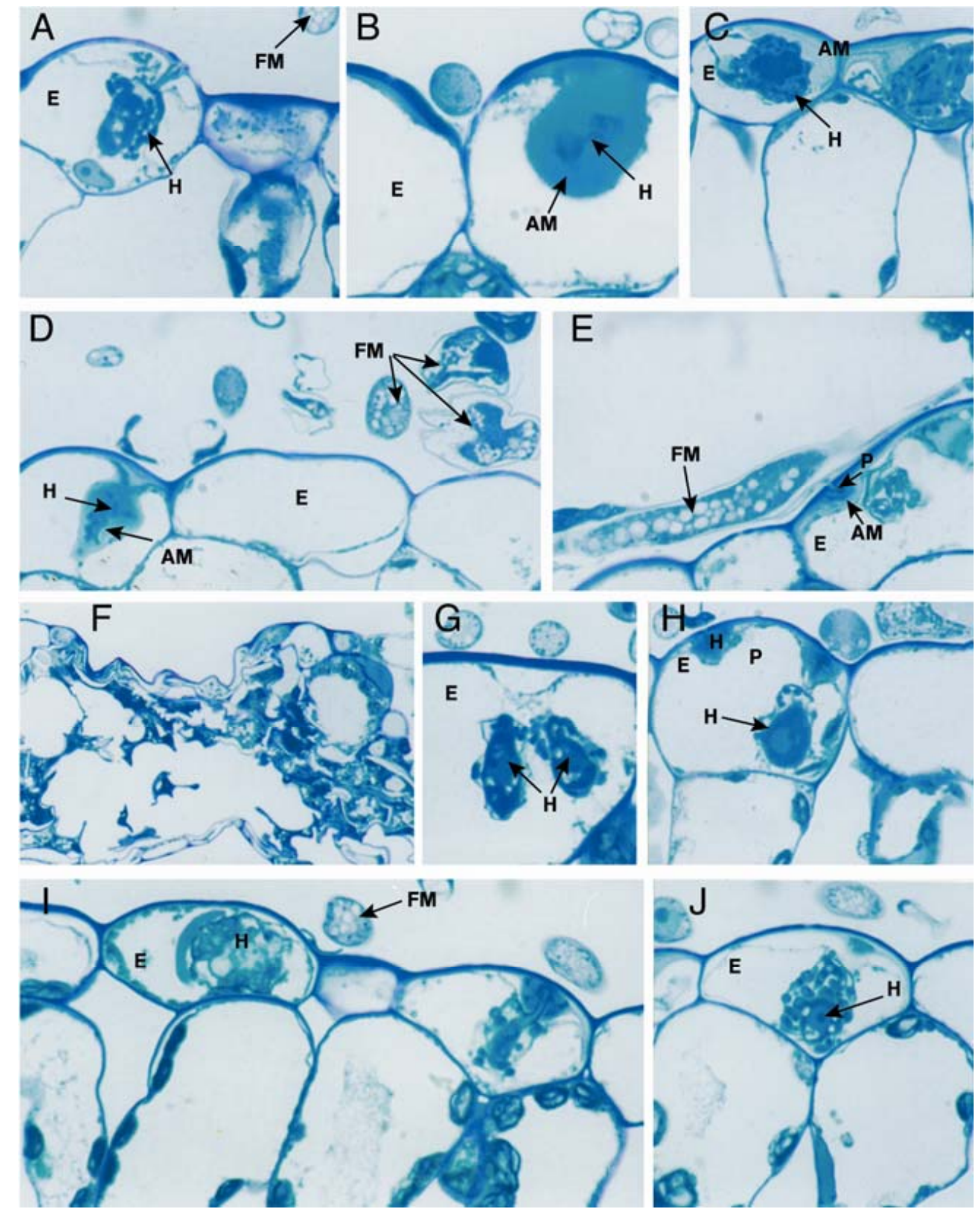

Fig. 4. Light micrographs of cucumber leaves infected with Podosphaera xanthii. Tissue samples were harvested 7 days after treatment with inhibitors, and resinembedded sections were stained with $0.2 \%$ toluidine blue $\mathrm{O}$ in $2 \%$ sodium borate. A, An inoculated nonelicited (I+M-) epidermal cell (E) containing a healthy multilobed fungal haustorium $(\mathrm{H})(\times 400)$. B to E, Inoculated elicited $(\mathrm{I}+\mathrm{M}+)$ leaves showing infected epidermal cells and the accumulation of amorphous material (AM) surrounding collapsed haustoria. Wall appositions were at times observed at fungal penetration sites $(\mathbf{B}, \times 1,000 ; \mathbf{C}$ to $\mathbf{E}, \times 400)$. F, Leaf tissue sample from an piperonylic acid-infiltrated $\mathrm{I}+\mathrm{M}+(\mathrm{PA})$ plant showing signs of phytotoxicity $(\times 400)$. G and $\mathbf{H}$, Fungal haustoria $(\mathrm{H})$ within the epidermal cells of 3,4methylenedioxy-infiltrated I+M+(MDCA) leaves $(\times 400)$. I and J, Ovoid, multilobed healthy haustoria within the epidermal cells (E) of cycloheximide-infiltrated $\mathrm{I}+\mathrm{M}+(\mathrm{CHX})$ cucumber leaf samples (X400). FM, fungal mycelium; and $\mathrm{P}$, papilla. 
lying induced resistance. The first defense reactions reported were associated with penetration resistance and were lignification of cell walls or formation of cell wall papilla $(8,20,21)$. Later, putative roles were demonstrated for PR proteins like chitinases, peroxidases, and $\beta$-1,3-glucanases $(11,22,29,36)$. Recently it was shown that powdery mildew-resistant cucumber plants also produced phytoalexins as a site-specific response to fungal penetration. Using fluorescence microscopy coupled with phytochemical analyses, McNally et al. (26) showed that rapidly synthesized $C$ glycosyl flavonoid phytoalexins accumulated exclusively within infected epidermal cells of disease-resistant plants.

Thus, plant pathologists are now faced with the challenge of evaluating the role of each response. Complicating this research are the obvious difficulties in untangling the contributions of defense responses, which naturally occur in synchrony within the tissues of diseased plants $(12,16,21)$. In this study, elicited cucumber plants expressing induced resistance against $P$. xanthii were infiltrated with potential inhibitors of $\mathrm{C} 4 \mathrm{H}, 4 \mathrm{CL}$, and $\mathrm{CHS}$ to evaluate the role of flavonoid phytoalexin production. Microscope and biochemical investigations supported the emerging hypothesis that induced resistance in cucumber is correlated with rapid, de novo biosynthesis of flavonoid phytoalexin compounds.

The level of induced resistance observed for elicited cucumber plants inoculated with $P$. xanthii confirmed previous findings related to the prophylactic effects of Milsana $(9,10,26)$. Light and electron microscope investigations of these plants corroborated the results obtained by Wurms et al. (41). For instance, collapsed, electron-dense fungal haustoria surrounded by an amorphous material were typical defense reactions observed for elicited plants during this study. A recent study examining phytoalexin production in cucumber demonstrated that an amorphous material sur- rounding collapsed haustoria contained high levels of the $C$ glycosyl flavonoid phytoalexins cucumerin A and B, along with minor $C$-glycosyl flavonoids such as vitexin, isovitexin, orientin, and isoorientin (26). These results obtained for elicited plants differed markedly from nonelicited plants, whose leaves supported dense fungal colonies and epidermis contained healthy multilobed fungal haustoria. It is worth noting that papillae were at times observed as an initial response to fungal penetration. Generally, papillae relate to powdery mildew fungal penetration in two ways: in some instances, penetration fails when papillae are present and alternatively, penetration may succeed and the papilla becomes a collar for the haustorial neck $(21,41)$. Using transmission electron microscopy, both outcomes were observed for elicited and nonelicited cucumber plants, strongly suggesting that papilla formation alone may not be sufficient to explain the level of induced resistance observed for elicited plants. Moreover, chitin labeling revealed that the walls and lobes of fungal haustoria within both treatments were undisturbed, suggesting that PR proteins, such as chitinases and $\beta$-1,3-glucanases, may not play a major role in the early events of induced resistance for cucumber.

Treatment of cucumber plants with $\mathrm{PA}$, an inhibitor of $\mathrm{C} 4 \mathrm{H}$, was phytotoxic as evidenced by highly necrotic leaf tissue and disorganization at the cellular level. Therefore, in this study it was not possible to form accurate conclusions regarding the role of $\mathrm{C} 4 \mathrm{H}$ in disease resistance for this pathosystem. Alternatively, infiltration with MDCA, an inhibitor of 4CL, had no toxic effect on leaves of $\mathrm{I}+\mathrm{M}+(\mathrm{MDCA})$ plants. In this case, a moderate level of infection coincided with the expression of induced resistance, albeit in a somewhat altered state. Light microscope observations confirmed that fungal haustoria within the epidermis of $\mathrm{I}+\mathrm{M}+(\mathrm{MDCA})$ plants were often collapsed and resembled those
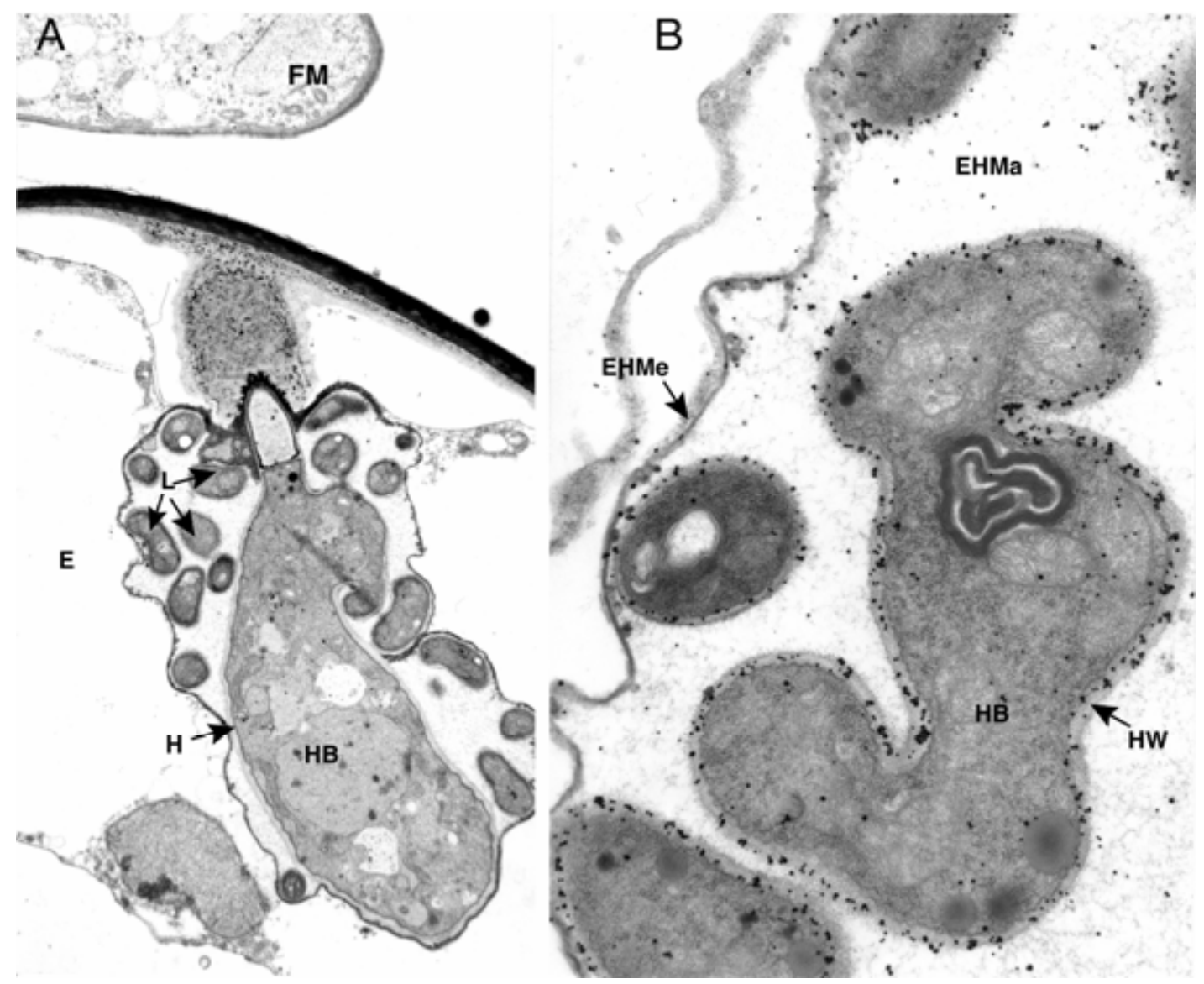

Fig. 5. Electron micrographs of ultrathin sections of nonelicited, Podosphaera xanthii-inoculated (I+M-) cucumber leaves. A, A well-developed healthy fungal haustorium $(\mathrm{H})(\times 6,000)$. B, Chitin localization showing specific deposition of gold particle labeling along the walls of the haustorial lobes $(\mathrm{L})$ and the haustorial main body $(\mathrm{HB})(\times 30,000)$. E, epidermal cell; EHMa, extra-haustorial matrix; EHMe, extra-haustorial membrane; FM, fungal mycelium; and HW, haustorial wall. 
observed within $\mathrm{I}+\mathrm{M}+$ plants, but the surrounding material was different (Figs. 6B and 7A). Since MDCA interferes primarily with the biosynthesis of lignin (19), these results suggest a minor role for lignification as a defense response in induced resistance in cucumber. Examination of I+M+(MDCA) plants with electron microscopy showed that defense reactions often differed from those observed in $\mathrm{I}+\mathrm{M}+$ plants and from other studies on Milsanaelicited defense reactions in cucumber (41). For instance, collapsed fungal haustoria within MDCA-infiltrated plants frequently were elongated and surrounded by granular material resembling callose. A possible explanation is offered by the fact that some 4CL-derived phenylpropanoids are used in the biosyn-
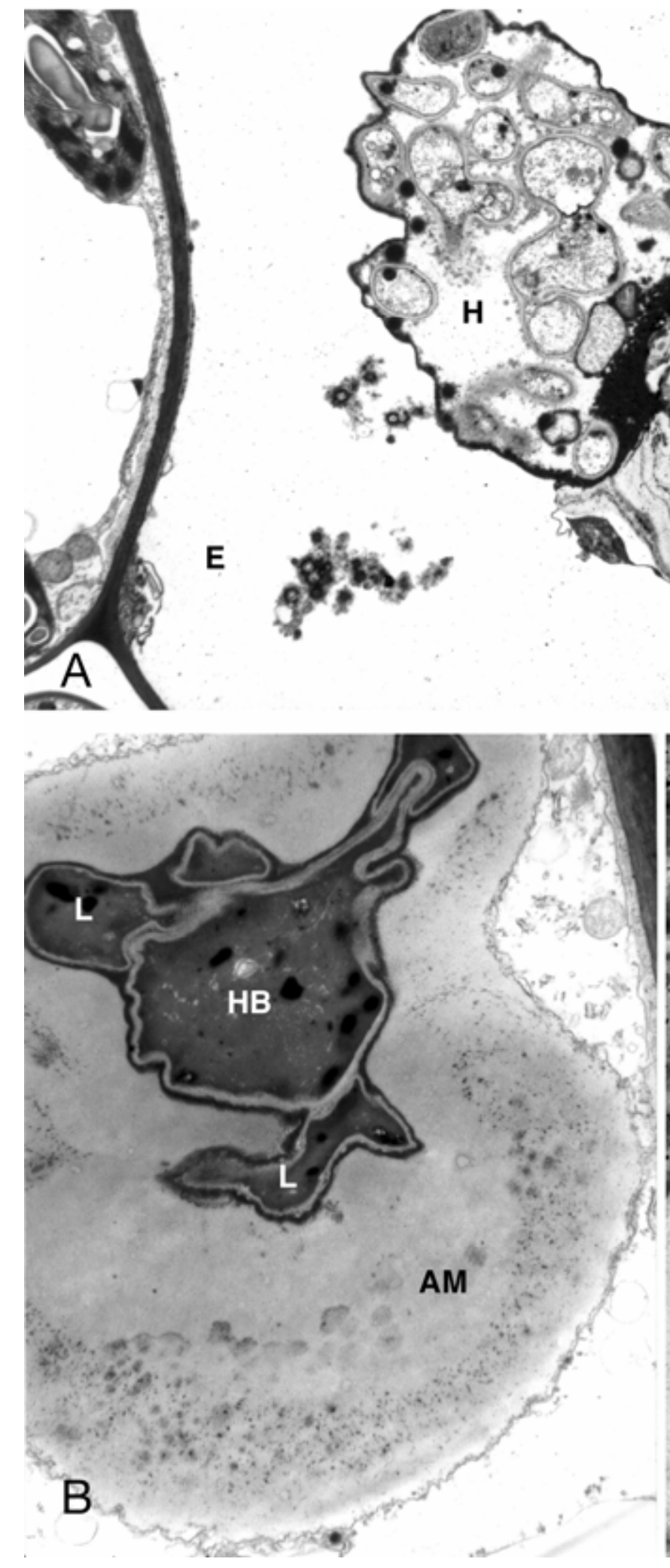

E

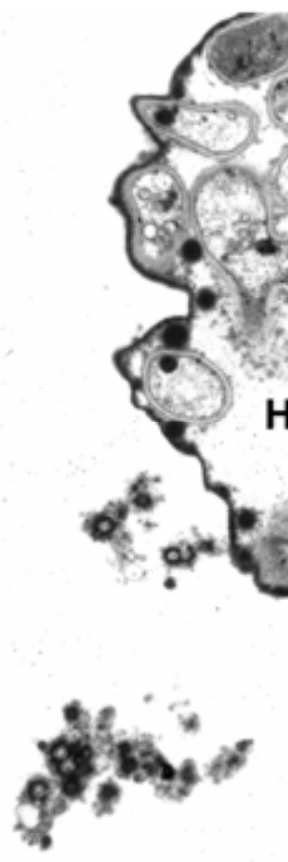

$\sin$

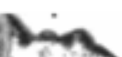

H

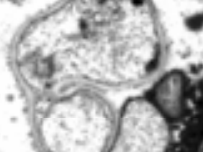

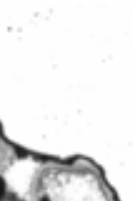
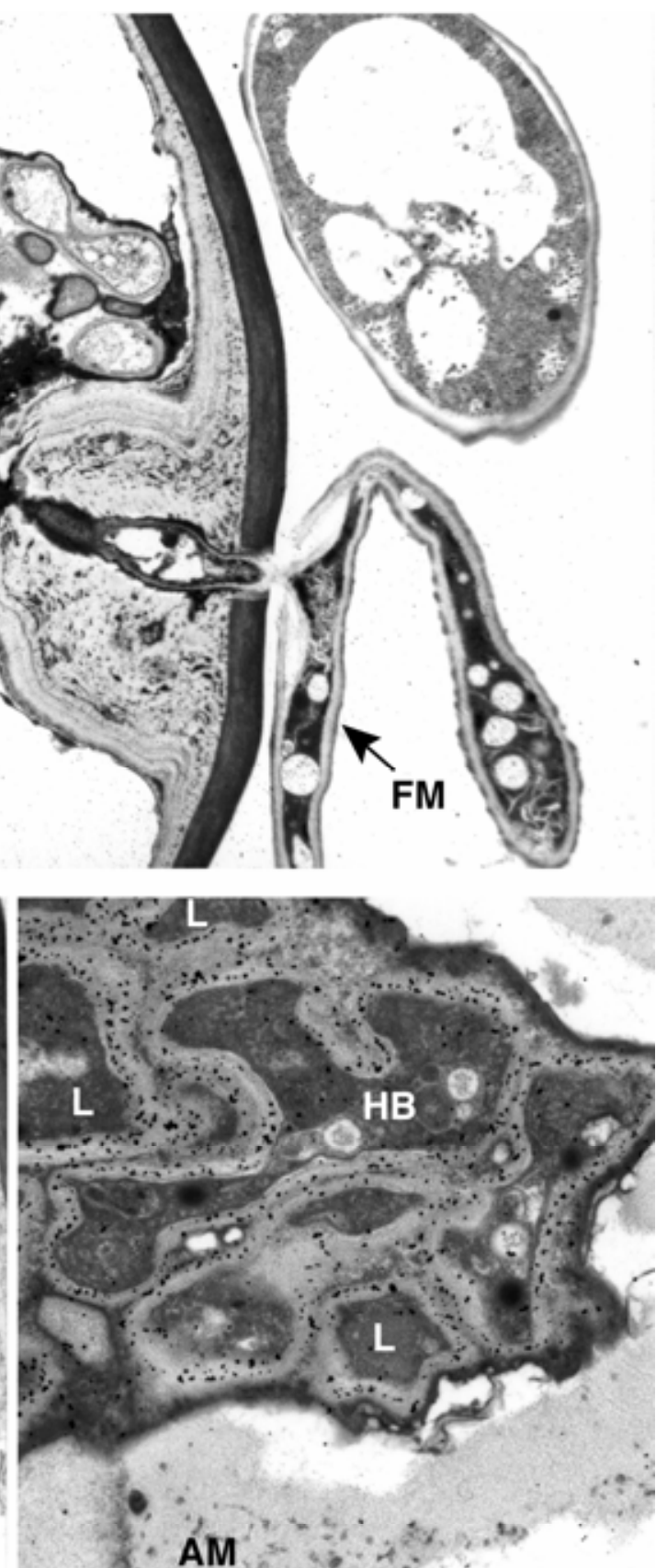

FM
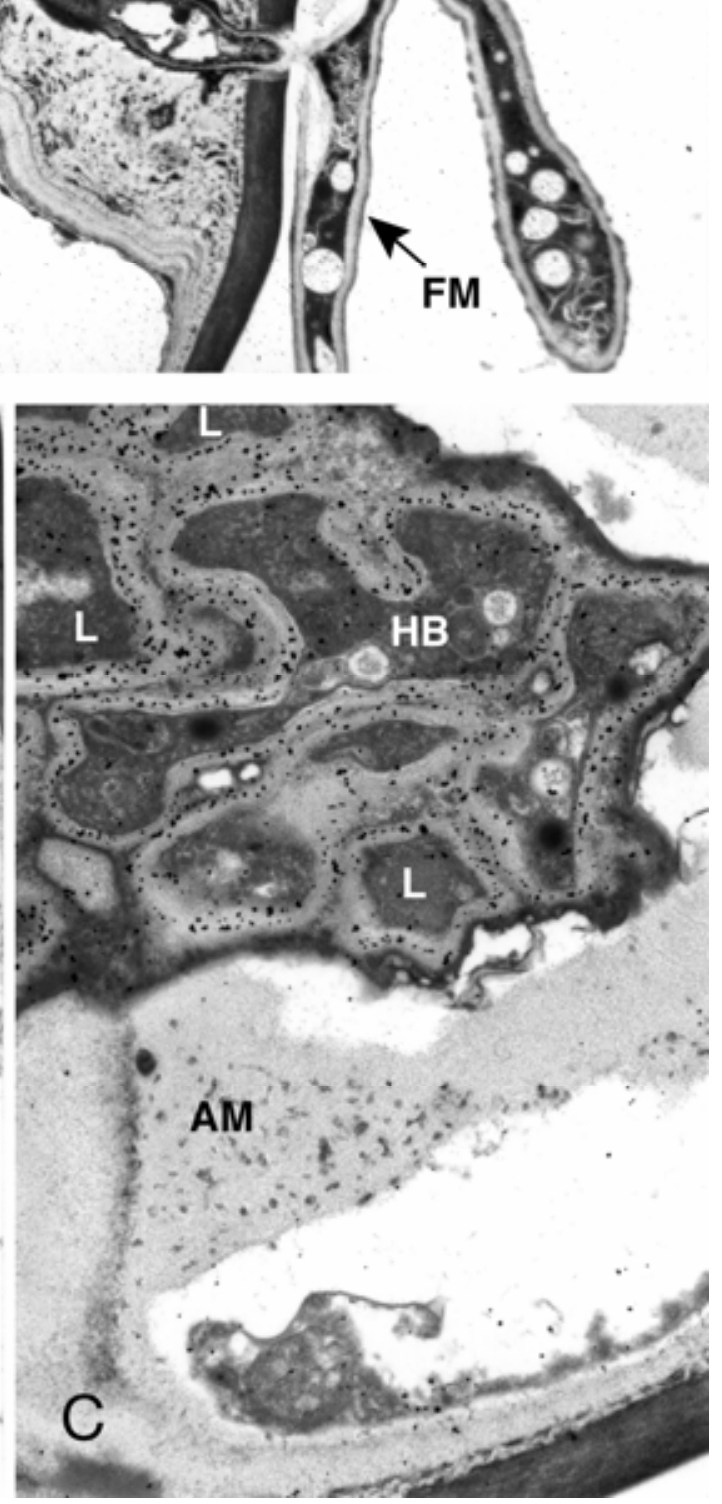

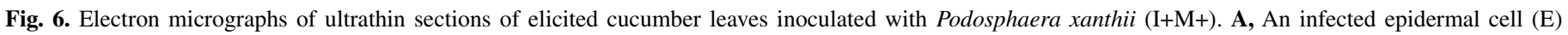

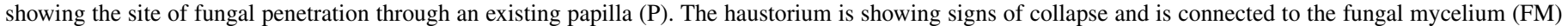

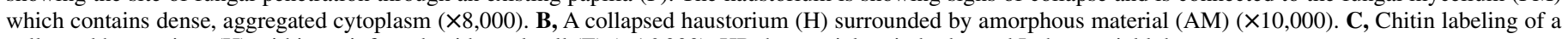
collapsed haustorium $(\mathrm{H})$ within an infected epidermal cell $(\mathrm{E})(\times 16,000)$. HB, haustorial main body; and L, haustorial lobe. 
thesis of flavonoid compounds (Fig. 1). For example, the B-rings of most flavonoids, including those of the flavonoid phytoalexins in cucumber, are synthesized directly from the C6-C3 phenylpropanoid metabolites in plants $(12,27)$. It is conceivable that disruption of $4 \mathrm{CL}$ in $\mathrm{I}+\mathrm{M}+(\mathrm{MDCA})$ plants reduced the concentration of the phenylpropanoid metabolite pool and therefore caused a reduction in flavonoid phytoalexin biosynthesis. This may explain the difference in defense reactions often observed for $\mathrm{I}+\mathrm{M}+(\mathrm{MDCA})$ plants and the higher level of infection on the leaves of these plants.

Infiltration with $\mathrm{CHX}$ resulted in a nearly complete loss of induced resistance in elicited plants. The leaves of $\mathrm{I}+\mathrm{M}+(\mathrm{CHX})$ plants supported dense fungal colonies paralleling disease severity observed for I+M- plants, and light microscope observations confirmed the development of healthy, multilobed fungal haus- toria within the epidermal cells of these plants. A closer examination with transmission electron microscopy showed that the internal structures of fungal haustoria within $\mathrm{I}+\mathrm{M}+(\mathrm{CHX})$ plants were clearly discernible and were free of the amorphous material observed in $\mathrm{I}+\mathrm{M}+$ plants. Biochemical analyses of $\mathrm{I}+\mathrm{M}+(\mathrm{CHX})$ plants revealed a clear correlation between CHS enzyme activity and induced resistance in cucumber. For instance, CHS activity was significantly lower in susceptible CHX-infiltrated plants compared with that in disease-resistant $\mathrm{I}+\mathrm{M}+$ plants. In fact, similar levels of CHS activity were observed for $\mathrm{I}+\mathrm{M}+(\mathrm{CHX})$ and nonelicited plants, reasonably suggesting that a comparable level of flavonoids may be produced in these two treatments. These results support the findings of a recent study that showed the leaves of cucumber plants elicited with Milsana containing 29 times more flavonoid phytoalexins compared with that of nonelicited
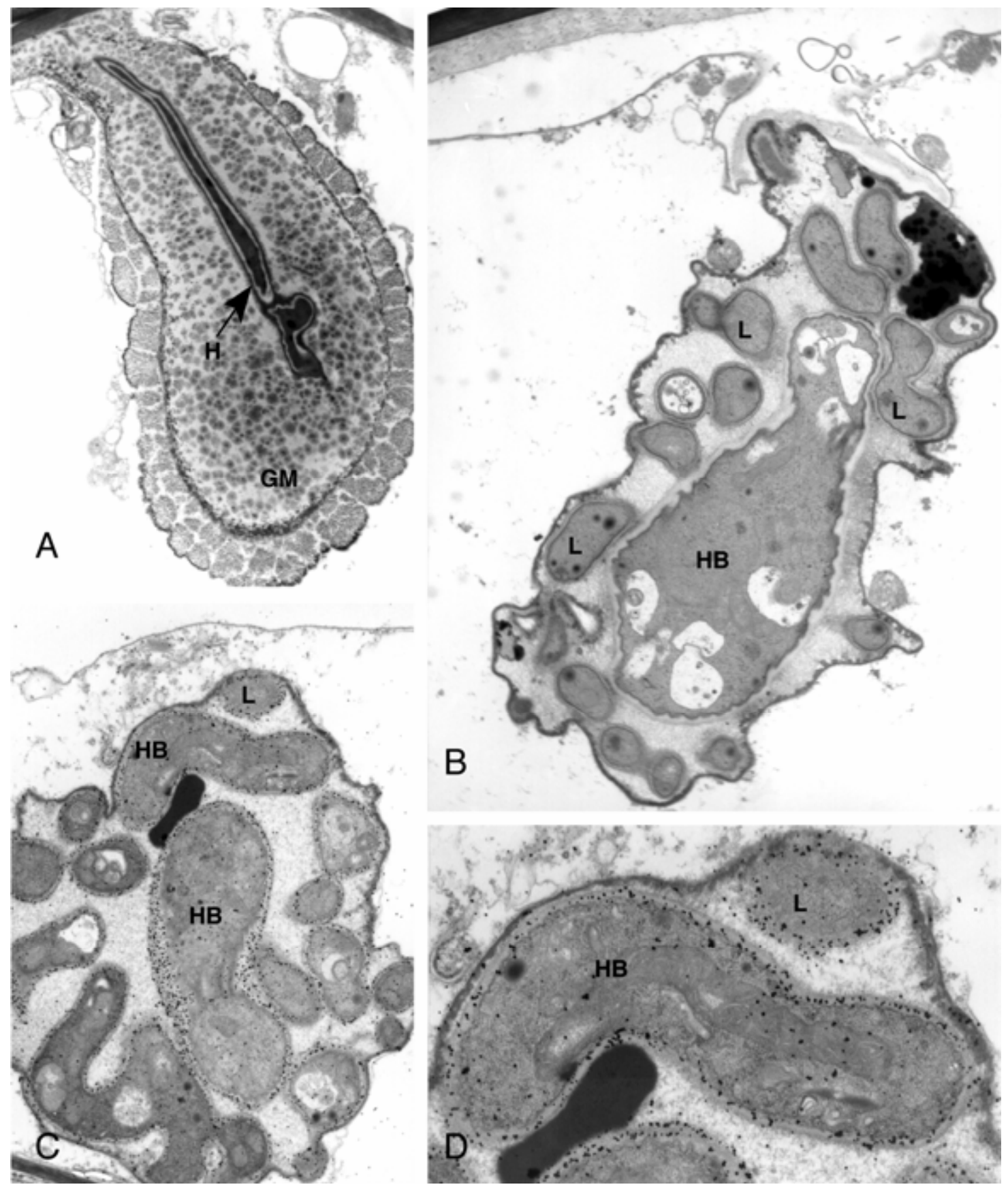

Fig. 7. Electron micrographs of ultrathin sections of elicited cucumber leaves inoculated with Podosphaera xanthii and infiltrated with 3,4-methylenedioxy cinnamic acid $\mathrm{I}+\mathrm{M}+(\mathrm{MDCA})$ or cycloheximide $\mathrm{I}+\mathrm{M}+(\mathrm{CHX})$. A, I+M+(MDCA) leaf with a poorly developed and collapsed haustorium (H) encased in a granular matrix $(\mathrm{GM})(\times 8,000)$. B, An I+M+(CHX) leaf showing a healthy multilobed fungal haustorium $(\mathrm{H})(\times 10,000)$. C and $\mathbf{D}$, Chitin localization within I+M+(CHX) leaves showing specific deposition of gold particle labeling within the walls of the haustorial lobes $(\mathrm{L})$ and main haustorial bodies $(\mathrm{HB})(\mathbf{C}, \times 10,000 ; \mathbf{D}, \times 24,000)$. 
plants (26). Of particular importance, phytotoxic reactions were never observed for CHX-infiltrated leaves and levels of $\beta$-glucosidase activity and 4CL synthesis resembled uninhibited plants, suggesting that $\mathrm{CHX}$-induced alteration of nontargeted function may be minimal. Nevertheless, there is a possibility that $\mathrm{CHX}$, as an inhibitor of translation, can interfere with the expression of other unmeasured proteins involved in resistance or of transcription factors that regulate CHS protein synthesis and, hence, down regulate this gene product. In conclusion, although direct causality cannot be established in absence of a specific inhibitor, this study presents for the first time strong evidence that induced resistance in cucumber can be suppressed through down regulation of CHS and disruption of the flavonoid pathway. This finding strongly suggests that flavonoid phytoalexins play a key role in determining the outcome of plant-powdery mildew interactions for this species. In contrast, other defense reactions reported to occur in cucumber such as lignification, papilla formation, and certain PR proteins may be relatively minor components contributing to induced disease resistance. Overall, the results of this study support the hypothesis that induced resistance in cucumber is largely correlated to de novo synthesis of flavonoid phytoalexin compounds.

\section{ACKNOWLEDGMENTS}

We thank E. Kombrink (MaxPlank Institute, Germany) and C. Douglas (University of British Columbia, Canada) for providing 4CL3 and 4CL2 constructs and A. Goulet and D. Auclair for excellent technical assistance. This work was supported by grants from the Natural Sciences and Engineering Research Council of Canada (NSERC); le Fonds pour la formation des Chercheurs et l'Aide à la Recherche to N. Benhamou, R. R. Bélanger, and A. Séguin; and the Canada Research Chairs program to R. R. Bélanger.

\section{LITERATURE CITED}

1. Allina, S. M., Pri-Hadash, A., Theilmann, D. A., Ellis, B. E., and Douglas, C. J. 1998. 4-Coumarate:coenzyme ligase in hybrid poplar. Plant Physiol. 116:743-754

2. Bashan, B., and Cohen, Y. 1983. Tobacco necrosis virus induces systemic resistance in cucumbers against Sphaerotheca fuliginea. Physiol. Plant Pathol. 23:137-144.

3. Benhamou, N., Rey, P., Chérif, M., Hockenhull, J., and Tirilly, Y. 1997. Treatment with the mycoparasite Pythium oligandrum triggers induction of defense-related reactions in tomato roots when challenged with Fusarium oxysporum f. sp. radicis-lycopersici. Phytopathology 87: 108-122.

4. Blount, J. W., Korth, K. L., Masoud, S. A., Rasmussen, S., Lamb, C., and Dixon, R. A. 2000. Altering expression of cinnamic acid 4-hydroxylase in transgenic plants provides evidence for a feedback loop at the entry point into the phenylpropanoid pathway. Plant Physiol. 122:107-116.

5. Carver, T. L. W., Zeyen, R. J., Bushnell, W. R., and Robbins, M. P. 1994. Inhibition of phenylalanine ammonia lyase and cinnamyl alcohol dehydrogenase increases quantitative susceptibility of barley to powdery mildew (Erysiphe graminis D.C.). Physiol. Mol. Plant Pathol. 44:261272.

6. Carver, T. L. W., Zeyen, R. J., Robbins, M. P., Vance, C. P., and Boyles, D. A. 1994. Suppression of host cinnamyl alcohol dehydrogenase and phenylalanine ammonia lyase increases oat epidermal cell susceptibility to powdery mildew penetration. Physiol. Mol. Plant Pathol. 44:243-259.

7. Christie, J. M., and Jenkins, G. I. 1996. Distinct UV-B and UV-A/blue light signal transduction pathways induce chalcone synthase gene expression in Arabidopsis cells. Plant Cell 8:1555-1567.

8. Conti, G. G., Bassi, M., Carminucci, D., Gatti, L., and Bocci, A. M. 1990. Preinoculation with tobacco necrovirus enhances peroxidase activity and lignification in cucumber, as a resistance response to Sphaerotheca fuliginea. J. Phytopathol. 128:191-202.

9. Daayf, F., Ongena, M., Boulanger, R., Hadrami, I. E., and Bélanger, R. R. 2000. Induction of phenolic compounds in two cultivars of cucumber by treatment of healthy and powdery mildew-infected plants with extracts of Reynoutria sachalinensis. J. Chem. Ecol. 26:1579-1593.

10. Daayf, F., Schmitt, A., and Bélanger, R. R. 1997. Evidence of phytoalexins in cucumber leaves infected with powdery mildew following treatment with leaf extracts of Reynoutria sachalinensis. Plant Physiol. 113:719-727.
11. Dalisay, R. F., and Kuć, J. A. 1995. Persistence of induced resistance and enhanced peroxidase and chitinase activities in cucumber plants. Physiol. Mol. Plant Pathol. 47:315-327.

12. Dixon, R. A., and Paiva, N. L. 1995. Stress-induced phenylpropanoid metabolism. Plant Cell 7:1085-1097.

13. Ehlting, J., Büettner, D., Wang, O., Douglas, C. J., Somssich, I. E., and Kombrink, E. 1999. Three 4-coumarate:coenzyme A ligases in Arabidopsis thaliana represent two evolutionarily divergent classes in angiosperms. Plant J. 19:9-20.

14. Fawe, A., Abou-Zaid, M., Menzies, J. G., and Bélanger, R. R. 1998. Silicon-mediated accumulation of flavonoid phytoalexins in cucumber. Phytopathology 88:396-401.

15. Feldbrügge, M., Hahlbrock, K., and Weisshaar, B. 1996. The transcriptional regulator CPRF1: Expression analysis and gene structure. Mol. Gen. Genet. 251:619-627.

16. Feys, B. J., and Parker, J. E. 2000. Interplay of signaling pathways in plant disease resistance. Trends Genet. 16:449-455.

17. Fofana, B., McNally, D. J., Labbé, C., Boulanger, R., Benhamou, N., Séguin, A., and Bélanger, R. R. 2002. Milsana-induced resistance in powdery mildew-infected cucumber plants correlates with the induction of chalcone synthase and chalcone isomerase. Physiol. Mol. Plant Pathol. 61:121-132.

18. Frens, G. 1973. Controlled nucleation for regulation of the particle size in monodisperse gold suspensions. Nature (Lond.) 241:20-22.

19. Funk, C., and Brodelius, P. E. 1990. Phenylpropanoid metabolism in suspension cultures of Vanilla planifolia Andr: II. Effects of precursor feeding and metabolic inhibitors. Plant Physiol. 94:95-101.

20. Hammerschmidt, R., and Kuć, J. 1982. Lignification as a mechanism for induced systemic resistance in cucumber. Physiol. Plant Pathol. 20:61-72.

21. Hammerschmidt, R., and Yang-Cashman, P. 1995. Pages 63-85 in: Induced Resistance in Cucurbits. R. Hammerschmidt and J. Kuć, eds. Kluwer Academic Publishers, The Netherlands.

22. Herger, G., and Klingauf, F. 1990. Control of powdery mildew fungi with extracts of the giant knotweed, Reynoutria sachalinensis (Polygonaceae). Med. Fac. Landbouwwet. Univ. Gent. 55:1007-1014.

23. Kircher, S., Ledger, S., Hayashi, H., Weisshaar, B., Schaefer, E., and Frohnmeyer, H. 1998. CPRF4a, a novel plant bZIP protein of the CPRF family: Comparative analyses of light-dependent expression, posttranscriptional regulation, nuclear import and heterodimerisation. Mol. Gen. Genet. 257:595-605.

24. Lee, D., and Douglas, C. J. 1996. Two divergent members of a tobacco 4coumarate:coenzyme A ligase (4CL) gene family. Plant Physiol. 112:193205.

25. Lo, S. C. C., and Nicholson, R. L. 1998. Reduction of light-induced anthocyanin accumulation in inoculated sorghum mesocotyls: Implications for a compensatory role in the defense response. Plant Physiol. 116:979-989.

26. McNally, D. J., Wurms, K., Labbé, C., and Bélanger, R. R. 2004. Synthesis of $C$-glycosyl flavonoid phytoalexins as a site-specific response to fungal penetration in cucumber. Physiol. Mol. Plant Pathol. 63:293-303.

27. McNally, D. J., Wurms, K., Labbé, C., Quideau, S., and Bélanger, R. R. 2003. Complex C-glycosyl flavonoid phytoalexins from Cucumis sativus. J. Nat. Prod. 66:1280-1283.

28. Meng, H., and Campbell, W. H. 1997. Facile enzymic synthesis of caffeoyl CoA. Phytochemistry 44:605-608.

29. Métraux, J. P., Streit, L., and Staub, T. 1988. A pathogenesis-related protein in cucumber is a chitinase. Physiol. Mol. Plant Pathol. 33:1-10.

30. Ni, W., Fahrendorf, T., Ballance, M. G., Lamb, C. J., and Dixon, R. A. 1996. Stress responses in alfalfa (Medicago sativa L.). XX. Transcriptional activation of phenylpropanoid pathway genes in elicitor-induced cell suspension cultures. Plant Mol. Biol. 30:427-438.

31. Nicot, P. C., Bardin, M., and Dik, A. J. 2002. Basic methods for epidemiological studies of powdery mildews: Culture and preservation of isolates, production and delivery of inoculum, and disease assessment. Pages 8399 in: The Powdery Mildews: A Comprehensive Treatise. R. R. Bélanger, W. R. Bushnell, A. J. Dik, and T. L. W. Carver, eds. The American Phytopathological Society, St. Paul, MN.

32. O’Neill, S. D., Tong, Y., Spoerlein, B., Forkmann, G., and Yoder, J. I. 1990. Molecular genetic analysis of chalcone synthase in Lycopersicon esculentum and an anthocyanin-deficient mutant. Mol. Gen. Genet. 224:279-288.

33. Orr, J. D., Edwards, R., and Dixon, R. A. 1993. Stress responses in alfalfa (Medicago sativa L.). XIV. Changes in the levels of phenylpropanoid pathway intermediates in relation to regulation of L-phenylalanine ammonia-lyase in elicitor-treated cell-suspension cultures. Plant Physiol. 101:847-856.

34. Politycka, B. 1998. Phenolics and the activities of phenylalanine ammonia-lyase, phenol-beta-glucosyltransferase and beta-glucosidase in cucumber roots as affected by phenolic allelochemicals. Acta Physiol. Plant 20:405-410. 
35. Ragg, H., Kuhn, D. N., and Hahlbrock, K. 1981. Coordinated regulation of 4-coumarate:coenzyme A ligase (EC 6.2.1.12) and phenylalanine ammonia-lyase (EC 4.3.1.5) messenger RNA in cultured plant cells. J. Biol. Chem. 256:10061-10065.

36. Rasmussen, J. B., Hammerschmidt, R., and Zook, M. N. 1991. Systemic induction of salicylic acid accumulation in cucumber after inoculation with Pseudomonas syringae pv. syringae. Plant Physiol. 97:13421347.

37. Schalk, M., Cabello-Hurtado, F., Pierrel, M. A., Atanossova, R., Saindrenan, P., and Werk-Reichhart, D. 1998. Piperonylic acid, a selective, mechanism-based inactivator of the trans-cinnamate 4-hydroxylase: A new tool to control the flux of metabolites in the phenylpropanoid pathway. Plant Physiol. 118:209-218.

38. Sewalt, V. J. H., Ni, W., Blount, J. W., Jung, H. G., Masoud, S. A., Howles, P. A., Lamb, C., and Dixon, R. A. 1997. Reduced lignin content and altered lignin composition in transgenic tobacco down-regulated in expression of L-phenylalanine ammonia-lyase or cinnamate 4-hydroxylase. Plant Physiol. 115:41-50.

39. Stuible, H. P., Büettner, D., Ehlting, J., Hahlbrock, K., and Kombrink, E. 2000. Mutational analysis of 4-coumarate:CoA ligase identifies functionally important amino acids and verifies its close relationship to other adenylate-forming enzymes. FEBS Lett. 467:117-122.

40. Welle, R., Schroeder, G., Schiltz, E., Grisebach, H., and Schroeder, J. 1991. Induced plant responses to pathogen attack: Analysis and heterologous expression of the key enzyme in the biosynthesis of phytoalexins in soybean (Glycine max L. Merr. cv. Harosoy 63). Eur. J. Biochem. 196:423-430.

41. Wurms, K., Labbé, C., Benhamou, N., and Bélanger, R. R. 1999. Effects of Milsana and benzothiadiazole on the ultrastructure of powdery mildew haustoria on cucumber. Phytopathology 89:728-736. 